\title{
Periplocin from Cortex periplocae inhibits cell growth and down-regulates survivin and c-myc expression in colon cancer in vitro and in vivo via B-catenin/TCF signaling
}

\author{
LIANMEI ZHAO ${ }^{1}$, BAOEN SHAN $^{1}$, YANYAN DU ${ }^{1}$, MINGXIA WANG ${ }^{2}$, LIHUA LIU $^{1}$ and FENG-ZHI REN ${ }^{3}$ \\ ${ }^{1}$ Research Center, ${ }^{2}$ Department of Clinical Pharmacology, The Fourth Hospital, Hebei Medical University, Hebei 050011; \\ ${ }^{3}$ New Drug Research and Development Co., Ltd., North China Pharmaceutical Corporation, Hebei 050015, P.R. China
}

Received February 18, 2010; Accepted April 27, 2010

DOI: $10.3892 /$ or_00000870

\begin{abstract}
Cancer of the colon and rectum is the third most commonly diagnosed cancer and accounts for approximately $10 \%$ of all cancer-related deaths. Although surgical resection or radiotherapy are potentially curative for localized disease, advanced colon cancer is currently associated with poor prognosis. Therefore, the development of a new and effective chemotherapeutic agent is required to target critical pathways to induce responsiveness of colon cancer cells to death signals. Dysregulation of the B-catenin/TCF pathway plays a central role in early activities of colorectal carcinogenesis. In this study, human colon cancer SW480 cells were used to investigate the effect of CPP (periplocin from Cortex periplocae) on the modulation of the B-catenin/ TCF signaling pathway. Our research results showed that CPP caused a dose- and time-dependent inhibition of cell growth as assessed by MTT assay and an induction in apoptosis as measured by flow cytometry and transmission electron microscopy. Furthermore, the CPP- treated cells were characterized by a decreased expression of $\beta$-catenin protein in the total cell lysates and cytosolic and nuclear extracts. This expression alleviates the binding activity of T-cell factor (Tcf) complexes to its specific DNA-binding sites. Thus, the protein expression of the downstream elements survivin and c-myc was down-regulated. To determine the precise inhibitory mechanisms involved, further in-depth in vivo studies of CPP are warranted. In conclusion, our data suggest that CPP wields a multi-prong strategy to target the ß-catenin/Tcf signaling pathway, leading to the induction of apoptosis and inhibition of growth of colon cancer cells in vitro and in vivo. Therefore, CPP may become a potential agent against colon cancer.
\end{abstract}

Correspondence to: Professor Baoen Shan, Research Center, The Fourth Hospital of Hebei Medical University, Shijiazhuang, Hebei 050011, P.R. China

E-mail: shanbaoen@163.com

Key words: periplocin, colon cancer cells, anti-tumor, ß-catenin/ TCF signaling, xenografts in nude mice

\section{Introduction}

The Wnt/ß-catenin pathway, one of the most crucial signaling pathways in cell proliferation and apoptosis, is highly conserved throughout cell evolution and regulates the expression of Wnt target genes through the $\beta$-catenin/T-cell factor (Tcf) $(1,2)$. Abnormal $\mathrm{Wnt} / \mathrm{B}$-catenin signaling is associated with a number of human diseases, including cancer, osteoporosis, aging and degenerative disorders $(2,3)$. 3 -catenin plays a dual role in this pathway in that when it translocates into the nucleus, it forms a complex with transcriptional factor TCF. TCF forms a complex with Groucho in the absence of $B$-catenin, and their interaction is thought to repress transcriptional activity. $\beta$-catenin interferes with the interaction between TCF and Groucho and induces the expression of downstream target genes such as survivin, c-myc and cyclin D1 (4). Activated B-catenin/Tcf signaling by accumulation of $\beta$-catenin in the nucleus plays a role in human carcinogenesis. More recently, approximately half of the largest samples of sporadic colorectal cancers and colorectal cancer cell lines lacking adenomatous polyposis coli (APC) mutations were shown to possess a somatic mutation in the $\beta$-catenin gene $(5,6)$. However, no therapeutic agents currently exist that selectively modulate the Wnt/B-catenin signaling pathway, although certain existing drugs (e.g., nonsteroidal anti-inflammatory drugs, vitamins and imatinib mesylate) have been confirmed to inhibit this pathway (7). Recently, the screening of anti-tumor components from Chinese medical herbs attracted interest (8-10).

Cortex periplocae $(\mathrm{CP})$ is the dry root of the traditional Chinese herb Periploca Sepium Bunge, referred to as Xiangjiapi in Chinese. It is a traditional type of medicine commonly used for a variety of clinical effects, including antiinflammation, enhancing bones and muscles and stimulating the nervous system (11). Itokawa et al (12) first found that periplocoside A from CP markedly inhibited the growth of ascite cancer S180 cells. In a previous study, an ethanolic extract from CP was isolated, verified as periplocin (CPP; Fig. 1) and found to significantly inhibit the growth of esophageal cancer, leukemia and colon cancer cells (13-15). However, the molecular mechanism of this extract has yet to be elucidated. The present study confirmed the induction of apoptosis of CPP in colon cancer cells via the $\beta$-catenin/Tcf 
signaling pathway and demonstrated that the downstream elements survivin and c-myc are involved in the apoptotic process of CPP. Furthermore, an in-depth in vivo study confirmed the efficacy of CPP against colon cancer mediated by the $ß$-catenin/Tcf pathway.

\section{Materials and methods}

Chemical substances. Periplocin extracted from CP (>96\% purity) (New Drug Research and Development Co., Ltd., North China Pharmaceutical Corp., Shijiazhuang, China) was dissolved in dimethylsulfoxide (DMSO) (Sigma Co., Germany) and diluted to final concentrations in each culture medium used as described below. Cells cultured in medium only were considered as the vehicle control group.

Cell lines and cell culture. Human colon carcinoma SW480 cells (Cellular Biology Institute of the Shanghai Academy of Sciences, Shanghai, China) were maintained in RPMI-1640 (Gibco) containing 10\% fetal calf serum (Sijiqing, Hangzhou, China), $100 \mathrm{U} / \mathrm{ml}$ penicillin, $100 \mu \mathrm{g} / \mathrm{ml}$ phytomycin (Invitrogen, USA) at $37^{\circ} \mathrm{C}$ in an incubator with a humidified atmosphere of $5 \% \mathrm{CO}_{2}$. After $\sim 80 \%$ confluence, the cultured cells were digested using $0.25 \%$ trypsin (Amresco, USA) and subcultured.

Cell viability assay. The effect of CPP on cancer cell viability was determined by MTT assay. The cells were plated at $1 \times 10^{4}$ per well in $100 \mu 1$ of complete culture medium and treated with $0.125,0.25,0.5,1.0$ and $2.0 \mu \mathrm{g} / \mathrm{ml}$ concentrations of CPP in 96-well microtiter plates (Costar, USA). Each concentration of CPP was repeated in 10 wells. After incubation for 24,48 and $72 \mathrm{~h}$ at $37^{\circ} \mathrm{C}$ in a humidified incubator, MTT [5 $\mathrm{mg} / \mathrm{ml}$ in phosphate-buffered saline (PBS)] was added to each well, and cells were incubated for $4 \mathrm{~h}$. The plate was then centrifuged at $1,500 \mathrm{x} \mathrm{g}$ for $5 \mathrm{~min}$. After careful removal of the medium, $0.1 \mathrm{ml}$ of buffered DMSO was added to each well, and the plates were shaken. The absorbance was recorded on a microplate reader (Titertek Multiskan, North Ryde, Austria) at a wavelength of $570 \mathrm{~nm}$. The effect of CPP on growth inhibition was assessed as the percentage of cell viability when the vehicle-treated cells were concurrently $100 \%$ viable.

Cell-morphology transmission electron microscopy. The apoptotic morphology of SW480 cells was determined by transmission electronic microscopy (TEM), as previously described $(16,17)$. Exponentially growing SW480 cells were seeded at $1.5 \times 10^{6}$ cells per $25-\mathrm{cm}^{2}$ flask and exposed to a CPP dilution $(0.5 \mu \mathrm{g} / \mathrm{ml})$ for $24 \mathrm{~h}$. Cells were fixed in $2.5 \%$ glutaraldehyde and washed with $0.075 \mathrm{M}$ phosphate buffer ( $\mathrm{pH} 7.4-7.6)$. The cells were then fixed in $0.25 \%$ aqueous osmium, dehydrated with increasing concentrations of ethanol $(30,50,70,90,100,100$ and 100\%) and embedded in quetol resin. Ultra-thin sections were prepared with a microtome and mounted on a copper grid. The samples were contrasted with $4 \%$ uranyl acetate and Reynolds' lead citrate. Samples were viewed with a multi-purpose Philips 301 TEM at the Electron Microscopy Unit of the Hebei Medical University (Shijiazhuang, China).

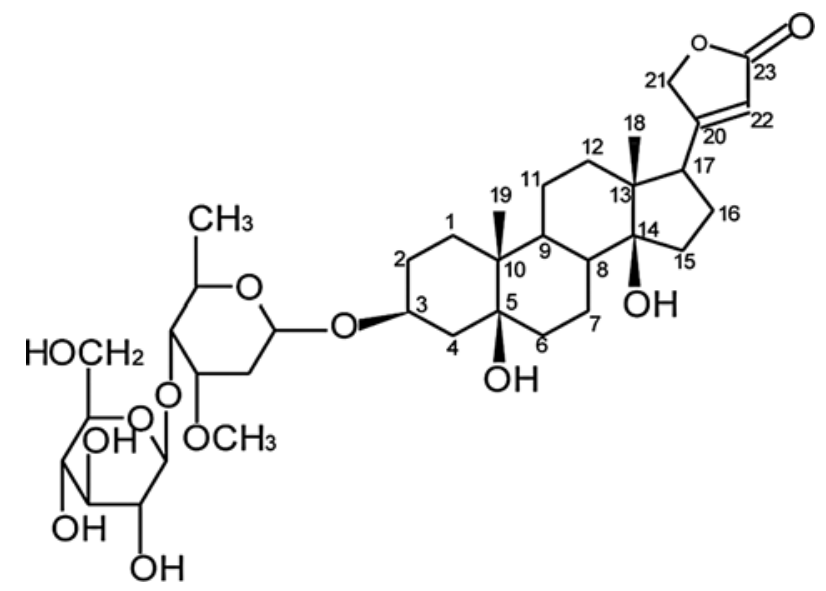

Figure 1. Structure of periplocin from Cortex periplocae (CPP) (identified by Professor Ren, New Drug Research and Development Co., Ltd. of North China Pharmaceutical Corporation, Shijiazhuang, China).

Analysis of apoptosis. Quantification of apoptotic cells was performed using propidium iodide (PI) (Sigma, St. Louis, MO, USA) staining according to the manufacturer's instructions. Briefly, cells were treated with CPP $(0.5 \mu \mathrm{g} / \mathrm{ml})$ for $0,6,12$ and $24 \mathrm{~h}$, then collected and resuspended in $500 \mu \mathrm{l} \mathrm{PBS}$ containing $50 \mathrm{mg} / \mathrm{ml} \mathrm{PI,} 0.1 \%$ Triton X-100, $0.1 \mathrm{mmol} / \mathrm{l}$ $\operatorname{EDTA}(\mathrm{Na})_{2}$ and $50 \mu \mathrm{g} / \mathrm{ml}$ RNase. After incubation in the dark for $30 \mathrm{~min}$, analysis was performed with a FACS flow cytometer (Becton-Dickinson, Sunnyvale, CA, USA) with $\mathrm{Ex}=488 \mathrm{~nm}$ and $\mathrm{Em}=530 \mathrm{~nm}$, using Cell Quest software. Cells in sub-G0 peak were regarded as apoptotic.

Confocal microscopy. Exponentially growing SW480 cells were seeded at $1 \times 10^{5} / \mathrm{ml}$ cells per well in a 6 -well plate which was loaded on coverslips in advance. After $24 \mathrm{~h}$ of attachment, the medium was discarded and the cells were exposed to vehicle medium or to a dilution of CPP $(0.5 \mu \mathrm{g} / \mathrm{ml})$ and incubation was carried out for $24 \mathrm{~h}$. The cells were washed twice with PBS, permeabilized with $0.5 \%$ Triton $\mathrm{X}$ 100 for $10 \mathrm{~min}$ and blocked by goat blood serum at a room temperature for $30 \mathrm{~min}$. Rabbit anti-ß-catenin monoclonal antibody (sc-70509; Santa Cruz Biotechnology, Santa Cruz, CA, USA) was added and incubation was carried out overnight at $4^{\circ} \mathrm{C}$. Rabbit secondary antibody (Zhongshan, Beijing, China) was then added and incubation was carried out for $60 \mathrm{~min}$ in the dark. The distribution of $\beta$-catenin protein was observed using Leica confocal laser scanning microscope (Zeiss, Germany).

Isolation of cellular and nuclear extracts. Proteins were obtained as previously described (18). Briefly, cells were trypsinized, and the whole cell protein was obtained by lysing the cells on ice for $20 \mathrm{~min}$ in $700 \mu \mathrm{l}$ lysis buffer [0.05 M Tris- $\mathrm{HCl}$ (pH 7.4), $0.15 \mathrm{M} \mathrm{NaCl}, 1 \%$ Nonidet P-40, $0.5 \mathrm{M}$ PMSF, $50 \mu \mathrm{g} / \mathrm{ml}$ aprotinin, $10 \mu \mathrm{g} / \mathrm{ml}$ leupeptin, $50 \mu \mathrm{g} / \mathrm{ml}$ pepstatin, $0.4 \mathrm{mM}$ sodium orthovanadate, $10 \mathrm{mM}$ sodium fluoride and $10 \mathrm{mM}$ sodium pyrophosphate]. The lysate was then sonicated for $20 \mathrm{sec}$, spun at $1,500 \mathrm{x} \mathrm{g} / \mathrm{min}$ for $10 \mathrm{~min}$, and the supernatant was collected. The nuclear pellets were prepared by resuspending cells in $800 \mu 1$ lysis buffer [10 mM 
Table I. Primers and conditions used in the reverse transcriptase-polymerase chain reaction.

\begin{tabular}{|c|c|c|c|}
\hline Name & Sequence & Conditions & No. of cycles \\
\hline B-catenin & $\begin{array}{l}\text { F: 5'-CGCATGGAGGAGATAGTTG-3' } \\
\text { R: 5'-CGAAAGCCGTTTCTTGTAG-3' }\end{array}$ & $\begin{array}{l}90^{\circ} \mathrm{C} \text { for } 60 \mathrm{sec}, 55^{\circ} \mathrm{C} \text { for } 60 \mathrm{sec}, 72^{\circ} \mathrm{C} \text { for } 60 \mathrm{sec} \text {, } \\
55^{\circ} \mathrm{C} \text { for } 60 \mathrm{sec} \text { and } 72^{\circ} \mathrm{C} \text { for } 60 \mathrm{sec}\end{array}$ & 35 \\
\hline Survivin & $\begin{array}{l}\text { F: 5'-AGCCCTTTCTCAAGGACCAC-3' } \\
\text { R: 5'-GCACTTTCTTCGCAGTTTCC-3' }\end{array}$ & $\begin{array}{l}90^{\circ} \mathrm{C} \text { for } 60 \mathrm{sec}, 55^{\circ} \mathrm{C} \text { for } 60 \mathrm{sec}, 72^{\circ} \mathrm{C} \text { for } 60 \mathrm{sec} \text {, } \\
55^{\circ} \mathrm{C} \text { for } 60 \mathrm{sec} \text { and } 72^{\circ} \mathrm{C} \text { for } 60 \mathrm{sec}\end{array}$ & 38 \\
\hline c-myc & $\begin{array}{l}\text { F: 5'-CCTACCCTCTCAACGACAGC-3' } \\
\text { R: 5'-GTTGTGTGTTCGCCTCTTGA-3' }\end{array}$ & $\begin{array}{l}90^{\circ} \mathrm{C} \text { for } 60 \mathrm{sec}, 55^{\circ} \mathrm{C} \text { for } 60 \mathrm{sec}, 72^{\circ} \mathrm{C} \text { for } 60 \mathrm{sec} \text {, } \\
55^{\circ} \mathrm{C} \text { for } 60 \mathrm{sec} \text { and } 72^{\circ} \mathrm{C} \text { for } 60 \mathrm{sec}\end{array}$ & 35 \\
\hline B-actin & $\begin{array}{l}\text { F: 5'-TGAGACCTTCAACACCCCAG-3' } \\
\text { R: 5'-GCCATCTCTTGCTCGAAGTC-3' }\end{array}$ & $\begin{array}{l}90^{\circ} \mathrm{C} \text { for } 60 \mathrm{sec}, 55^{\circ} \mathrm{C} \text { for } 60 \mathrm{sec}, 72^{\circ} \mathrm{C} \text { for } 60 \mathrm{sec} \text {, } \\
55^{\circ} \mathrm{C} \text { for } 60 \mathrm{sec} \text { and } 72^{\circ} \mathrm{C} \text { for } 60 \mathrm{sec}\end{array}$ & 35 \\
\hline
\end{tabular}

HEPES (pH 7.8), $10 \mathrm{mM} \mathrm{KCl,} 2 \mathrm{mM} \mathrm{MgCl}_{2}$ and $0.1 \mathrm{mM}$ EDTA], placing them on ice for $15 \mathrm{~min}$ and then vigorously mixing after the addition of $50 \mu \mathrm{l}$ of $10 \%$ Nonidet P-40. Following a $30-\mathrm{sec}$ centrifugation $\left(12,000 \mathrm{x} \mathrm{g}, 4^{\circ} \mathrm{C}\right)$, the pelleted nuclei were resuspended in $120 \mu 1$ extraction buffer $[50 \mathrm{mM}$ HEPES (pH 7.8), $50 \mathrm{mM} \mathrm{KCl,} 300 \mathrm{mM} \mathrm{NaCl}, 0.1 \mathrm{mM}$ EDTA and $10 \%$ glycerol] and incubated on ice for $30 \mathrm{~min}$. Nuclear extracts were stored at $-70^{\circ} \mathrm{C}$. For the preparation of cytoplasmic proteins, cell pellets were suspended in $800 \mu 1$ lysis buffer (see whole cell protocol) without Tween-20 detergent, the pulse was sonicated ( 1 sec $\times$ 30$)$ on ice and then spun at $10,000 \mathrm{x} g$ for $1 \mathrm{~h}$. The supernatant (cytoplasmic fraction) was collected as usual.

Western blot analysis. Western blot analysis was performed on SW480 cells for the presence of B-catenin on the whole extract, cytosol or nuclear proteins, survivin and c-myc. Whole cell proteins, nuclear extracts and cytoplasmic proteins were isolated as described above. Equal loading of the protein groups on the blots was evaluated using BCA assay. Protein samples (20-100 $\mu \mathrm{g}$ ) were loaded onto a 10\% SDS-PAGE gel and run at $120 \mathrm{~V}$ for $2 \mathrm{~h}$ and transferred to a nitrocellulose filter (NC filter; Amersham, Arlington Heights, IL, USA) for $2 \mathrm{~h}$ at $135 \mathrm{~mA}$. The membranes were blocked with $5 \%$ milk in TBST overnight, washed three times and incubated with the primary Ab (anti- $\beta$-catenin, anti-survivin and anti-c-myc; Santa Cruz Biotechnology) for $2 \mathrm{~h}$ at room temperature. The membranes were washed three times with TBST and incubated for $1 \mathrm{~h}$ with fluorochrome-labeled secondary anti-rabbit IgG (IRDye 800-LI-COR; Odyssey). After four washings with TBST, the membrane was imaged with a LI-COR Odyssey infrared imager (application note http://www.licor.com/bio/ Odyssey2/Odyssey13.jsp).

Electrophoretic mobility shift assay (EMSA). To detect Bcatenin/Tcf-DNA binding, EMSA was performed using the Lightshift ${ }^{\mathrm{TM}}$ chemiluminiscent kit (Pierce, Rockford, IL, USA) following the manufacturer's protocol. DNA was biotinlabeled using the biotin 3' end-labeling kit (Pierce). Briefly, in a $50-\mu 1$ reaction buffer, 5 pmol of double-stranded Tcf oligonucleotide 5'-CCCTTTGATCTTACC-3' and 3'-GGGAAA CTAGAATGG-5', $10 \mu 1$ of $5 \mathrm{X}$ terminal deoxynucleotidyl transferase (TdT) buffer, $5 \mu \mathrm{l}$ of $5 \mu \mathrm{M}$ biotin-N4-CTP, 10 units of diluted TdT and $25 \mu \mathrm{l}$ of ultra-pure water were incubated at $37^{\circ} \mathrm{C}$ for $30 \mathrm{~min}$. Each binding reaction contained $1 \mathrm{X}$ binding buffer, $0.05 \%$ NP-40, $5 \mu \mathrm{g}$ of nuclear extract and 20-50 fmol of biotin end-labeled target DNA. The content was incubated at room temperature for $20 \mathrm{~min}$. A measurement of $5 \mathrm{ml}$ of $5 \mathrm{X}$ loading buffer was added to this reaction mixture, subjected to gel electrophoresis on a native polyacrylamide gel and transferred to a nylon membrane. When the transfer was complete, DNA was cross-linked to the membrane at $120 \mathrm{~mJ} / \mathrm{cm}^{2}$ using a UV cross-linker equipped with 254-nm bulbs. The biotin end-labeled DNA was detected using streptavidin-horseradish peroxidase conjugate and a chemiluminescent substrate. The membrane was exposed to $\mathrm{X}$-ray film and developed using a Kodak film processor.

Reverse transcriptase-polymerase chain reaction ( $R T-P C R)$ analysis. Total RNA was extracted from the treated cells using TRI Reagent (Sigma, USA) according to the manufacturer's instructions. RT-PCR was conducted as previously described (20), with some modifications. In brief, cDNA was prepared using RNA samples (3-5 $\mu \mathrm{g}$ ) to which $1 \mu \mathrm{g}$ oligo(dT)18, $0.5 \mathrm{mM}$ dNTP and 200 units of Revert Aid ${ }^{\mathrm{TM}}$ H-Minus M-MuLV RT enzyme were added (MBI Fermentas, USA). PCR analysis was performed using selective primers (Table I) (synthesized at Sangon, Shanghai, China), and $2 \mu 1$ of RT product was incubated with 1 unit of Taq DNA polymerase in a $50-\mu 1$ reaction mixture containing $1 \mathrm{mM}$ dNTP and $1.5 \mathrm{mM} \mathrm{MgCl}_{2}$ (Promega, USA). The amplified fragments were detected in $1.5 \%(\mathrm{w} / \mathrm{v})$ agarose gel and analyzed using an IS1000 image analysis system (Alpha Innotech, San Leandro, CA, USA).

In vivo experiments using nude mice. Forty nude Balb/c mice, 4 to 6 weeks old, were obtained from the Animal Research Center of the Chinese Academy of Medical Science (Beijing, China), quarantined for 1 week and housed in an animal holding room under controlled conditions. After each mouse was intraperitoneally implanted with $0.2 \mathrm{ml}$ of $5 \times 10^{5}$ SW480 cells on Day 0 , the mice were randomly divided into two groups ( $n=20$ per group). Mice intended for CPP treatment were intraperitoneally injected with CPP at a dose rate of $30 \mathrm{mg} / \mathrm{kg} /$ day for 12 days, whereas the 20 mice intended for vehicle treatment were administered an equal volume of normal saline. During the course of the study, tumor volumes of all mice were measured according to the formula $\left(1 / 2 \times\right.$ length $\mathrm{x}$ width $\left.{ }^{2}\right)$ every 3 days, until all mice were sacrificed. The animals were sacrificed 12 days after 


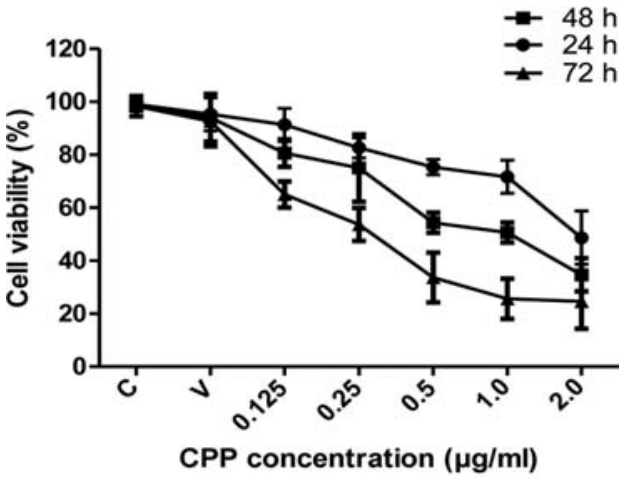

Figure 2. Effects of CPP on the viability of SW480 cells. Cells were treated with specific concentrations of CPP for 24,48 and $72 \mathrm{~h}$, and cell viability was determined by MTT assay. The values are represented as the percentage of viable cells when control cells were regarded as $100 \%$ viable. Data represent the mean percentage of viable cells \pm SD of three independent experiments.

tumor cell injection. The peritoneally disseminated tumor masses were collected and weighed together. Tumor tissues from 10 mice of each group were fixed in $10 \%$ buffered formalin and processed for histopathological evaluation by routine procedures (21). The expression of $ß$-catenin, survivin and c-myc in the tumor tissues of the other 10 mice in each group was measured by an immunohistochemistry assay as previously described (22). Specifically, tumor tissue sections were subjected to routine methods. Antigen retrieval was achieved by microwaving in $0.01 \mathrm{~mol} / \mathrm{l}$ citrate buffer. The endogenous peroxidase activity was inhibited by incubating with $3 \%$ hydrogen peroxide in methanol, and non-specific binding was blocked. After washing three times with PBS, the specimens were left to react overnight at $4^{\circ} \mathrm{C}$ with anti- $\beta$ catenin, anti-survivin and anti-c-myc antibodies (Santa Cruz Biotechnology). Following incubation with peroxidaseconjugated secondary antibody (Zhongshan), the signal was developed with 3,3-diaminobenzidine tetrahydrochloride in Tris- $\mathrm{HCl}$ buffer ( $\mathrm{pH} 7.6$ ) containing $0.02 \%$ hydrogen peroxide. The sections were then counterstained with hematoxylin and mounted. The experimental protocol was approved by the Animal Care and Use Committee of the Hebei Medical University.

Statistical analysis. One-way analysis of variance (ANOVA) was performed to determine the significance between the two groups, and the t-test was used to compare two independent samples. Fisher's probability was used to analyze the difference in protein expression between the two groups. $\mathrm{P}<0.05$ or 0.01 was considered to be statistically significant, and the results represent the mean $\pm \mathrm{SD}$. Results shown in the figures were obtained from at least three independent experiments with a similar pattern. All data analyses were performed using SPSS 13.0 software.

\section{Results}

CPP inhibits the growth of SW480 cells. As shown in Fig. 2, CPP significantly inhibited the growth of colon cancer SW480 cells in a dose- and time-dependent manner. Cells hardly grew in the presence of $1.0 \mu \mathrm{g} / \mathrm{ml} \mathrm{CPP}$. $\mathrm{IC}_{50}$ values for



Control
CPP $(0.5 \mu \mathrm{g} / \mathrm{ml})$



Figure 3. Apoptotic morphology in CPP-treated SW480 cells. SW480 cells were stimulated without or with $0.5 \mu \mathrm{g} / \mathrm{ml} \mathrm{CPP}$ for $24 \mathrm{~h}$, and the intracellular vacuole formation and cytoplasmic shrinking were observed with TEM.

24,48 and $72 \mathrm{~h}$ were $0.59,0.28$ and $0.15 \mu \mathrm{g} / \mathrm{ml}$, respectively. The results demonstrated the potency of CPP in inhibiting the growth of colon cancer cells in vitro.

Apoptotic morphology of SW480 cells induced by CPP. To understand the mechanism of CPP-induced cell death, morphological changes of SW480 cells induced by CPP were observed by TEM. Evidence of hypercondensed chromatin and cytoplasmic shrinking were observed in the $0.5 \mu \mathrm{g} / \mathrm{ml}$ CPP-treated SW480 cells (although not conclusive) revealing that CPP induced cell death through apoptosis in the SW480 cells (Fig. 3).

CPP treatment increases the rate of apoptosis in SW480 cells. To further detect apoptotic processes, the level of apoptosis in the CPP-treated SW480 cells was determined using PI staining. A time-dependent increase in the cell population in the sub-G1 phase of the cell cycle was noted (Fig. 4). In the vehicle medium, only $3.46 \%$ of the total cell population was apoptotic. In contrast, 13.6, 20.22 and $36.52 \%$ of the cell population were apoptotic when the cells were exposed to $0.50 \mu \mathrm{g} / \mathrm{ml} \mathrm{CPP}$ for 6,12 and $24 \mathrm{~h}$, respectively.

CPP affects the localization and expression of $\beta$-catenin. As the contribution of $\beta$-catenin to tumorigenesis increases, it mediates the signal transduction cascades that play an important role in regulating apoptosis. Previous findings suggest that nuclear $\beta$-catenin accumulation plays an important role in $\mathrm{Wnt} / \mathrm{B}$-catenin pathway activation and transcription of downstream target genes. We investigated the effect of CPP on the location and expression level of ß-catenin. Following immunofluorescence staining and confocal microscopy analysis, we found that the majority of the B-catenin protein was expressed in the nucleus and cytoplasm of the control cells (Fig. 5A-a), while after treatment with CPP $(0.5 \mu \mathrm{g} / \mathrm{ml})$ for $24 \mathrm{~h}$, the expression level of $B$-catenin decreased significantly in that its expression level was higher in the cytoplasm than that expressed in the cytoplasts (Fig. 5A-b). Based on this result, we hypothesized that the expression level of $\beta$-catenin was modified. Therefore, we detected the expression level of the $\beta$-catenin protein in total cell lysates, endochylema and cytoblasts, and its mRNA expression in the cells. Our results showed that after SW480 cells were treated with CPP $(0.125,0.5$ and $2.0 \mu \mathrm{g} / \mathrm{ml})$ for 
A

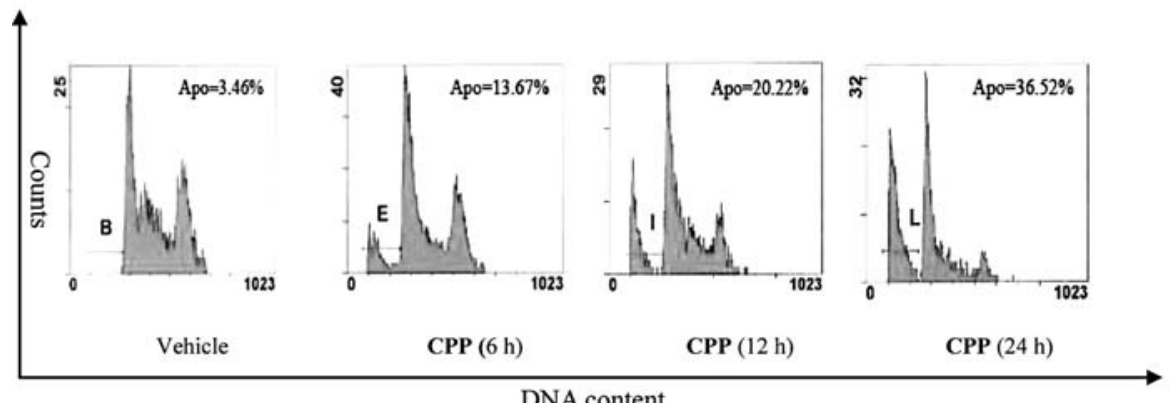

B

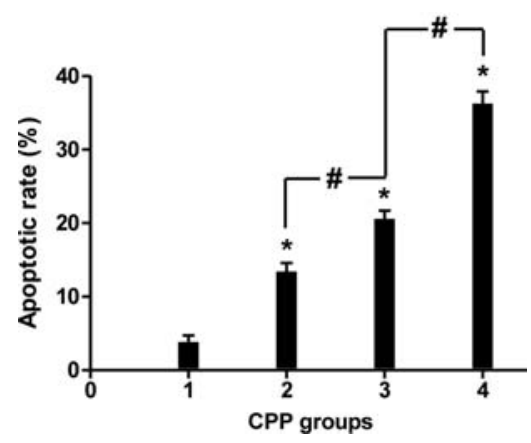

Figure 4. Effect of CPP on the apoptosis of SW480 cells treated with $0.5 \mu \mathrm{g} / \mathrm{ml} \mathrm{CPP}$ for 6,12 and $24 \mathrm{~h}$. (A) The cells were stained with PI, and the total DNA content was measured to analyze the apoptotic rate (in the sub-G1 peak) by flow cytometry. (B) The apoptotic rate of the cells was analyzed by Mod Fit LT 3.0. Bars, mean of three independent plates. ${ }^{*} \mathrm{P}<0.01$, compared to the control group $(0 \mathrm{~h})$; ${ }^{\text {"P }}<0.01$, compared between the two groups. Lane 1 , control; 2-4, CPP treatment for 6, 12 and $24 \mathrm{~h}$.

A

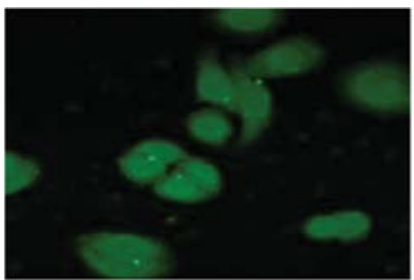

a

$\mathbf{B}$

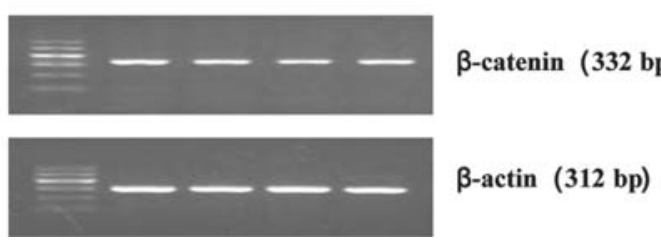

C

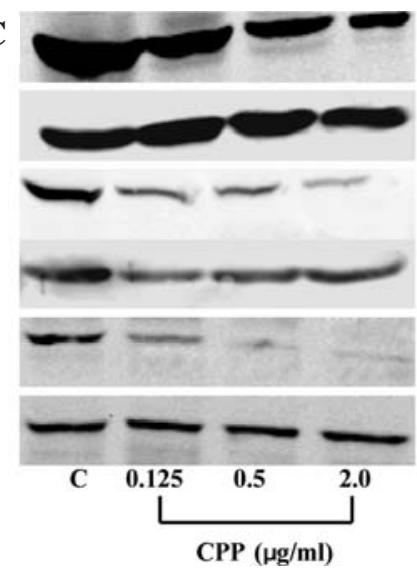

b

$\beta$-catenin in cytosolic

GAPDH in cytosolic

$\beta$-catenin in nuclear

GAPDH in nuclear

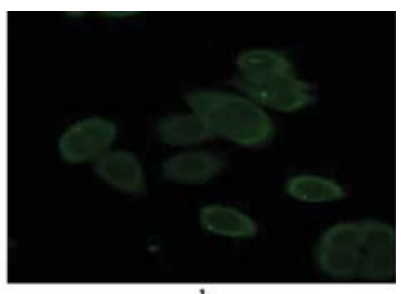

B-catenin in total cell lysate

GAPDH in total cell lysate

Figure 5. Subcellular distribution of $\beta$-catenin in SW480 cells. (A) Control cells (a), and cells after exposure to CPP $(0.5 \mu \mathrm{g} / \mathrm{ml})$ for $24 \mathrm{~h}$ (b). Cells were subjected to confocal immunofluorescence assay (x400) using anti- $\beta$-catenin antibody staining. Effects of CPP on (B) the transcriptional level and (C) protein expression level of $\beta$-catenin in SW480 cells. Expression levels of $\beta$ catenin mRNA and protein were measured by RT-PCR and Western blotting as described in Materials and methods. Representative results from three independent experiments are shown.

$24 \mathrm{~h}$, the protein expression of $\beta$-catenin in the total protein, endochylema and cytoblasts decreased significantly in a dosedependent manner (Fig. 5C), while the expression of ß-catenin
C $\quad 0.125 \quad 0.5 \quad 2.0 \mathrm{CPP}(\mu \mathrm{g} / \mathrm{ml})$

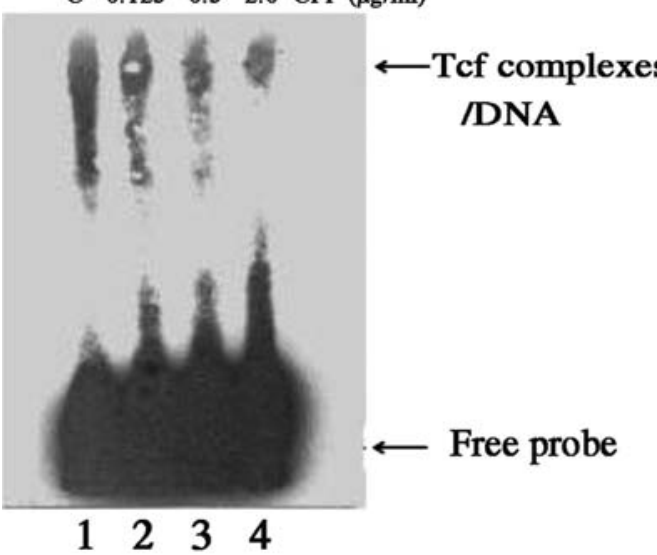

Figure 6. The binding activity of the B-catenin/Tcf complex to DNA decreased with CPP. SW480 cells were treated with CPP for $24 \mathrm{~h}$, and nuclear extracts were isolated. EMSA was performed with a mixture of $5 \mu \mathrm{g}$ nuclear extracts from the cells treated without (lane 1) or with CPP at different concentrations (lanes 2-4) and biotin-labeled DNA strands as described in Materials and methods.

mRNA did not markedly change (Fig. 5B), indicating that $\mathrm{CPP}$ influenced the expression of $\beta$-catenin at the protein but not at the transcriptional level.

CPP diminishes the binding activity of the TCF compound with its DNA sequence. B-catenin binds with the transcription factor of lymphocyte enhancer-binding factor (LEF)/TCF in the nucleus to form a complex which stimulates the expression of downstream genes $(23,24)$. Therefore, we considered the possibility that the decreased expression of $\beta$ catenin in the nucleus impedes the binding of the B-catenin/ Tcf complex to its specific DNA strands. Nuclear extracts derived from CPP-treated cells were analyzed by EMSA assay for their ability to associate with biotin-labeled oligonucleotide-containing Tcf response elements. It was found that the nuclear protein extracted from the vehicle-treated cells was able to sufficiently bind with specific DNA, and the retarded band was prominent (Fig. 6, lane 1). On the other hand, the binding ability of the Tcf complex from the CPP- 
A

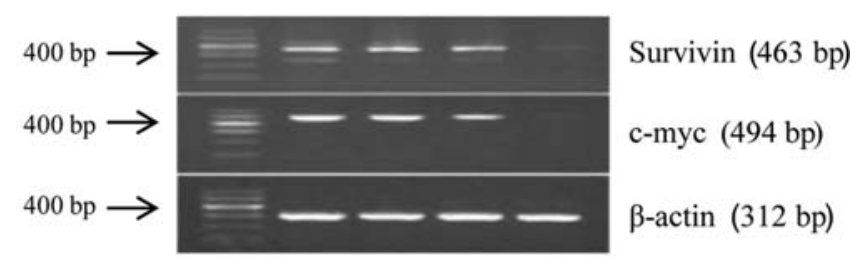

B

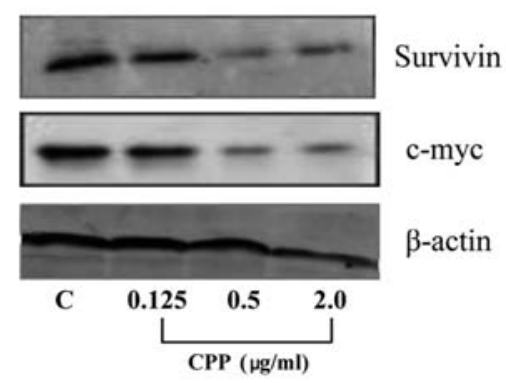

Figure 7. (A) B-catenin/Tcf target gene survivin and c-myc mRNA and (B) protein expression in SW480 cells treated with CPP were detected by RTPCR and Western blot analysis. The images are representative of three independent experiments. Lane 1, control; 2, $0.125 \mu \mathrm{g} / \mathrm{ml} \mathrm{CPP;} 3,0.5 \mu \mathrm{g} / \mathrm{ml}$ CPP and $4,2.0 \mu \mathrm{g} / \mathrm{ml} \mathrm{CPP}$.

treated cell nucleus with its DNA strand was weak, and the retarded band became superficial (Fig. 6, lanes 2-4) in a dosedependent manner. This demonstrated that CPP interfered with the binding activity of Tcf complexes to its specific DNA.

$m R N A$ and protein expression of survivin and c-myc. ß-catenin/ Tcf-mediated signaling regulates a diverse set of genes responsible for cell proliferation, differentiation and homeostasis (25-29). To scrutinize which downstream factor accounts for the cell apoptosis induced by CPP, we examined the expression levels of the factors, including survivin and c-myc. As shown in Fig. 7, the expression levels of survivin and c-myc mRNA and proteins significantly decreased in CPP-treated cells compared to the vehicle-treated cells, which was consistent with the apoptotic process induced by CPP.

Effect of CPP on tumor growth in vivo. To further investigate whether CPP has a growth inhibitory effect on tumors in vivo, SW480 cells were implanted intraperitoneally into nude Balb/c mice. We examined the suppressing effects of a CPP intraperitoneal injection on peritoneally disseminated tumor masses of SW480 cells. The tumor volume in each mouse was recorded at an interval of 3 days to evaluate its retardation. The tumor volume data of the experimental groups are shown in Fig. 8A. After inoculation of colon cells, the tumor volume increased from Day 3 in the vehicle group until sacrifice, while the tumor volume did not significantly increase in the CPP mice. At the end of the experiment, tumor weight and volume in the CPP-treated animals were significantly less compared to those of the vehicle-treated mice (Fig. 8B). Average tumor volumes and weights were $1.763 \pm 0.300 \mathrm{~cm}^{3}$ and $3.550 \pm 0.675 \mathrm{mg}$ in the vehicle group and $0.515 \pm 0.184 \mathrm{~cm}^{3}$ and $1.367 \pm 0.398 \mathrm{mg}$ in the CPP-treated mice, a decrease of 71.01 and $61.49 \%$, respectively. These results suggest that CPP has an in vivo anti-tumor effect.
A

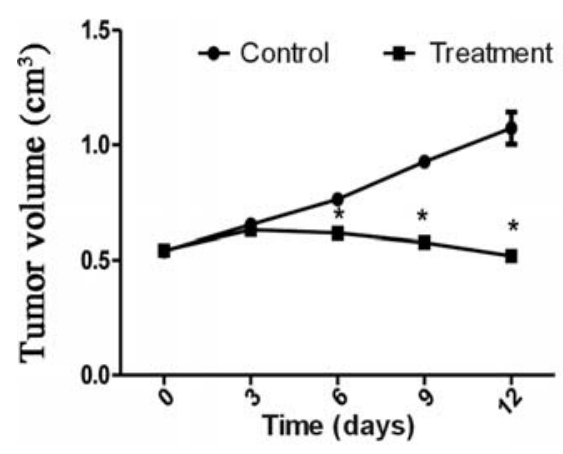

B



Figure 8 . Effect of CPP (30 mg/kg/day) on tumor growth in nude mice. CPP treatment was started when tumors had grown to $40-45 \mathrm{~mm}^{3}$ and was continued for 12 days. (A) From Day 3, the tumor volume of the treated mice was more than that of the control group, and the difference was significant. (B) On Day 12 of the experiment, tumor weight and volume in the CPP-treated animals were significantly less compared to those of the vehicle-treated mice. ${ }^{*} \mathrm{P}<0.01$, compared to the vehicle group.

Effect of CPP on histocyte morphosis of transplanted tumors and the expression level of $\beta$-catenin, survivin and $c$-myc in tumor tissue. Tumor tissue was widespread in the vehicletreated mice, but few tumor tissues reached the glandular tube in the CPP-treated mice. In contrast, tumor cell density in the carcinoma organism of the CPP group was lower, and the stroma was more than that of the vehicle group. Furthermore, compared to the vehicle group, there were more inflammatory cells and necrotic tissue in the CPP-treated mice (Fig. 9A, hematoxylin and eosin staining). The in vitro experiment showed that CPP affected the expression of B-catenin protein and its downstream factors survivin and c-myc in the tumor tissue by immunohistochemical staining assay. Results showed that the expression of $\beta$-catenin, survivin and c-myc in the tumor tissue of CPP-treated mice decreased compared to that expressed in the tumor tissue of the vehicle-treated mice (Fig. 9B), which was consistent with our data in vitro.

\section{Discussion}

This study confirmed the ethanolic extract periplocin (Fig. 1) to be one of the anti-tumor components of Cortex periplocae, and we elucidated the mechanism involved in the inhibition of proliferation of colon cancer cells. A time-dependent investigation was conducted over $72 \mathrm{~h}$, with intervals of 24 , 48 and $72 \mathrm{~h}$, using human colon carcinoma treated with $0.125-2.0 \mu \mathrm{g} / \mathrm{ml} \mathrm{CPP}$. A significant growth inhibition of the SW480 cells was shown over the entire period of the experiment compared to cells propagated in the growth 


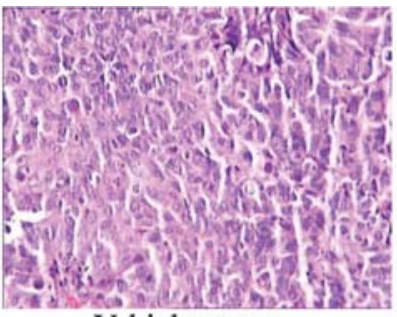

Vehicle group



CPP group

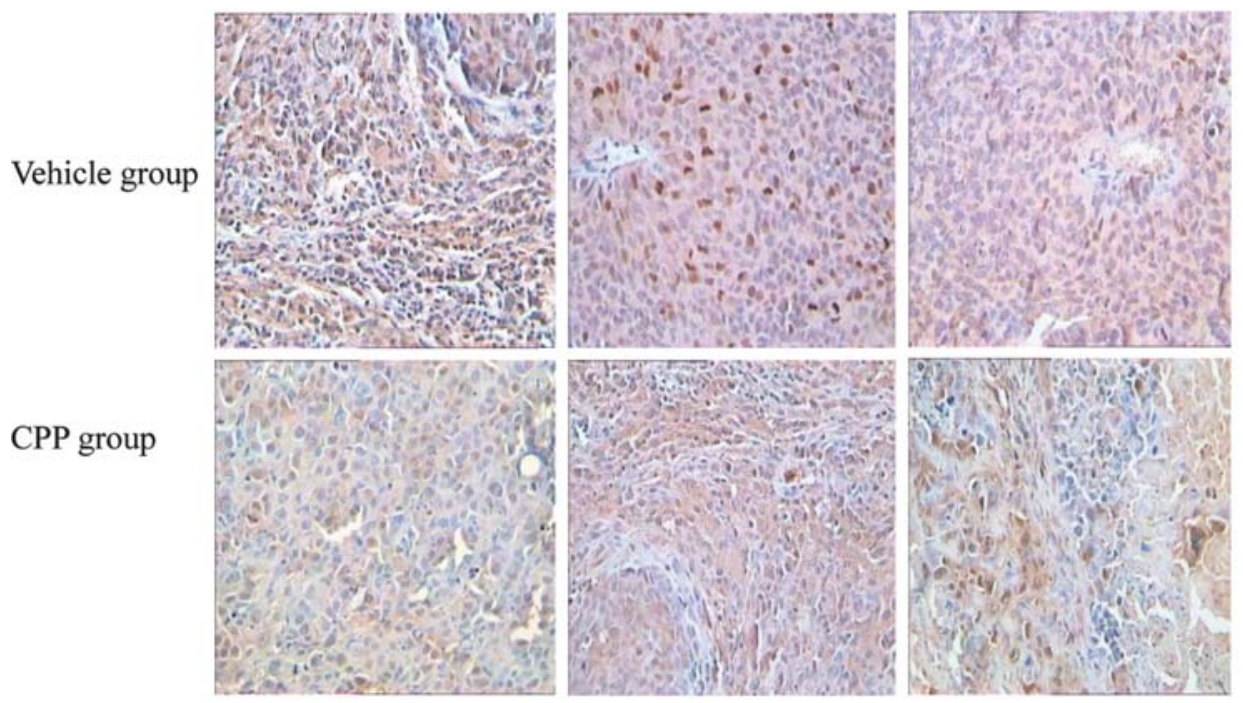

Figure 9. Histological appearance of SW480 human colon cancer cells injected into nude mice (A; streptavidin-peroxidase, x400) and expression of ß-catenin, survivin and c-myc protein in transplanted tumor organism (B; streptavidin-peroxidase, $\mathrm{x} 400)$. Tumor tissue from CPP-treated and control mice was subjected to immunohistochemical staining with anti- $\beta$-catenin, survivin and $c-m y c$.

medium. Morphological and flow cytometry analysis for the CPP-treated cells demonstrated an increase in apoptotic cells, suggesting that apoptosis plays a key role in the growth inhibitory effects of CPP.

It was reported that the activation and accumulation of the oncogenic $\beta$-catenin signaling pathway is not only an initiating event, but also plays a pivotal role in the promotion stage of colorectal carcinogenesis (30-34). In the event of no stimulation from the Wnt signal, $\beta$-catenin in the cytoplasm binds with proteins such as APC, Axin, casein kinase (CK)1a, 1e and GSK-3ß to form a complex that regulates tumor development. GSK-3ß phosphorylates $\beta$-catenin on serine 41,37 and 33 , and CK1 further phosphorylates B-catenin on the 45 serine/ threonine to promote degradation of the $B$-catenin protein based on ubiquitin $(35,36)$. Non-phosphorylated $\beta$-catenin is displaced to the nucleolus and facilitates LEF/TCF to activate the expression of downstream target genes, including survivin, c-myc, cyclin D1 and FGF18 (26-29), which are responsible for cell proliferation and apoptosis. Moreover, it is reported that elevated $\beta$-catenin levels promote early neoplastic change through oncogenic signaling within cells $(23,24)$. B-catenin signal transduction activity is abnormal in $90 \%$ of human colon carcinomas (34). The present study showed that CPP suppresses the $\mathrm{Wnt} / \mathrm{\beta}$-catenin signaling pathway by inhibiting nuclear $\beta$-catenin localization and by regulating the transcription of target genes.

Our previous studies and other studies $(18,37)$ showed that quercetin, one of the most common flavonoids, inhibits human SW480 colon cancer growth in association with the regulation of the $B$-catenin/Tcf signaling pathway. Aspirin, one of the non-steroidal anti-inflammatory drugs, was reported to inactivate $\beta$-catenin/Tcf signaling and inhibit the growth of colorectal cancer cells $(38,39)$. The present study demonstrated that CPP induces the inhibition of proliferation and apoptosis of SW480 cells by modulating the $\beta$-catenin/TCF signaling pathway. First, our results showed that CPP significantly reduces $\beta$-catenin expression at the protein, but not at the transcriptional level, suggesting that CPP influences the ß-catenin/ TCF signaling pathway via $\beta$-catenin, but has no effect on the upstream factors of the pathway. Moreover, the $\beta$-catenin expression decreased in total protein, endochylema and the cytoblast protein of the CPP-treated cells. In addition, following treatment with CPP, the decreased expression of $ß$-catenin in the cytoplasm resulted in a reduction in the $\beta$-catenin translocation to the nucleus, leading to the reduction of binding activity between the $B$-catenin/TCF complex and its specific DNA strands, thus its downstream target genes were not effectively transcripted. Down-regulation of the survivin and c-myc mRNA and protein expression, which was the final mechanism contributing to the anti-proliferation effects of CPP, was also noted. It has been reported that suvivin and c-myc are associated with colon cancer cell apoptosis $(28,32)$. We also demonstrated that c-myc is involved in the apoptosis induction mechanism of CPP. Survivin, a member of the inhibitor of apoptosis family proteins, is thought to be a bifunctional regulator of cell death and proliferation expressed during embryonic development, while it is undetectable in healthy adult tissues and re-expressed in a number of types of 
cancer, including colorectal (40-43). Studies of colon cancer cells suggest that the regulation of survivin expression is at least partially $ß$-catenin/TCF-dependent $(43,44)$. Our results suggest that the down-regulation of the survivin expression plays a role in the apoptosis of SW480 cells induced by CPP. To further investigate the effect of CPP on tumor growth in vivo, athymic nude mice models engrafted with SW480 cells were established. Data demonstrated that CPP inhibited the growth of the tumors in vivo. The volume and weight of transplanted tumors in the treatment groups were less than those of the vehicle group, and the percentage of inhibition was 71.01 and $61.49 \%$, respectively. Furthermore, the downregulation of the $\beta$-catenin/Tcf signaling pathway target genes, survivin and c-myc, contributed to the anti-proliferation of the tumors, consistent with the results of the in vitro experiment.

Based on the results of this study, periplocin from Cortex periplocae (CPP) highlights a multi-prong beneficial strategy for targeting the $\beta$-catenin/Tcf signaling pathway leading to apoptosis and the inhibition of growth of colon cancer cells. This may be explained by the modulation of B-catenin/Tcf mediated by down-regulation of its downstream elements, survivin and c-myc. Since colon cancer is resistant to conventional chemotherapeutic regimens, CPP is a potential agent that can overcome this resistance, which our in-depth in vivo study confirms. In conclusion, our results provided a firm basis for further research on this novel anti-tumor medicinal plant.

\section{Acknowledgements}

This study was supported by the Natural Science Foundation of China, grant no. 30371753 and organized by The Fourth Hospital of Hebei Medical University, China. The research student fellowship was granted by the Research Center, The Fourth Hospital of Hebei Medical Universtiy. We also thank New Drug Research and Development Co., Ltd., North China Pharmaceutical Corporation, China for the support.

\section{References}

1. Neson WJ and Nusse R: Convergence of Wnt, B-catenin, and cadherin pathways. Science 30: 31483-31487, 2004.

2. Clevers H: Wnt/beta-catenin signaling in development and disease. Cell 127: 469-480, 2006

3. Moon RT, Kohn AD, Ferriari GV and Kaykas A: Beta-catenin signaling: diseases and therapies. Nat Rev Genet 5: 691-701, 2002 .

4. Willert $\mathrm{K}$ and Jones KA: Wnt signaling: is the party in the nucleus? Genes Dev 20: 1394-1404, 2006.

5. Staal FJ and Sen JM: The canonical Wnt signaling pathway plays an important role in lymphopoiesis and hematopoiesis. Eur J Immunol 38: 1788-1794, 2008

6. Rubinfeld B, Alber I, Porfiri E, Fiol C, Munemitsu S and Polkis P: Binding of GSK3ß to the APC- $B$-catenin complex and regulation of complex assembly. Science 272: 1023-1026, 1996.

7. Fumi TY and Sasaguri: The Wnt//-catenin signaling pathway as a target in drug discovery. J Pharmacol Sci 104: 293-302, 2007.

8. Janssens N, Janicot M and Perera T: The Wnt-dependent signaling pathways as target in oncology drug discovery. Invest New Drugs 24: 263-280, 2006

9. Luu HH, Zhang R, Haydon RC, Rayburn E, Kang Q and Si W: Wnt/ß-catenin signaling pathway as novel cancer drug targets. Curr Cancer Drug Targets 4: 653-671, 2004

10. Luciano MN, Silva PH, Chaim OM, Santos VL, Franco CR and Soares MF: Experimental evidence for a direct cytotoxicity of Loxosceles intermedia (brown spider) venom in renal tissue. J Histochem Cytochem 52: 455-467, 2004.
11. National Committee of Pharmacopeia: Pharmacopoeia of the People's Republic of China (in Chinese). Chemical Industry Publishing Company, China, Beijing, p181, 2005.

12. Itokawa $\mathrm{H}, \mathrm{Xu} \mathrm{JP}$ and Takeya K: Studies on chemical constituents of antitumor fraction from Periploca sepium. V. Structures of new pregnane glycosides, periplocosides $\mathrm{J}, \mathrm{K}, \mathrm{F}$ and $\mathrm{O}$. Chem Pharm Bull 36: 4441-4446, 1988.

13. Zhang J, Shan BE and Liu GS: Apoptosis induced by ethyl acetate extract from Cortex Periplocae in human breast cancer cell line MCF-7. Tumor (in Chinese) 26: 418-421, 2006.

14. Zhao LM, Shan BE, Ai J, Ren FZ and Lian YS: Effects of periplocin from Cortex periplocae on proliferation of human esophageal carcinoma cells TE-13 and related mechanisms. Tumor (in Chinese) 28: 203-206, 2008.

15. Du YY, Liu X and Shan BE: Periplocin extract from Cortex periplocae induces apoptosis of SW480 cells through inhibiting the Wnt/B-catenin signaling pathway. Chin J Cancer (in Chinese) 28: 456-460, 2009

16. Stander A, Marais S, Stivaktas V, Vorster C, Albercht C and Lottering ML: In vitro effects of Sutherlandia frutescens water extracts on cell numbers, morphology, cell cycle progression and cell death in a tumorigenic and a non-tumorigenic epithelial breast cell line. J Ethnopharmacol 124: 45-60, 2009.

17. Naliwaiko K, Luvizon AC, Donatti L, Chammas R, Mercadante AF and Zanata SM: Guanosine promotes B16F10 melanoma cell differentiation through PKC-ERK 1/2 pathway. Chem Biol Interact 173: $122-128,2008$.

18. Park CH, Chang JY, Hahm ER, Park S, Kim HK and Yang CH: Quercetin, a potent inhibitor against $\beta$-catenin/Tcf signaling in SW480 colon cancer cells. Biochem Biophys Res Commun 328: 227-234, 2005.

19. Morceau F, Schnekenburger M, Blasius R, Buck I, Dicato M and Diederich M: Tumor necrosis factor alpha inhibits aclacinomycin A-induced erythroid differentiation of K562 cells via GATA-1. Cancer Lett 294: 525-540, 2006.

20. Liu LH, Wang SJ, Shan BE, Shao L, Sato A and Kawamura K: IL-27-mediated activation of natural killer cells and inflammation produce antitumor effects for human esophageal carcinoma cells. Scand J Rheumatol 68: 22-29, 2008.

21. Kawabata K, Tanaka T, Murakami T, Okada T, Murai H and Yamamoto T: Dietary prevention of azoxymethane-induced colon carcinogenesis with rice-germ in F344 rats. Carcinogenesis 20: 2109-2115, 1999.

22. Liu LH, Shan B and Feng YL: Antitumor effects and immunoregulation mechanisms of IL-23 gene in mouse mammary cancer mediated by retrovirus. Cell Immunol 258: 181-187, 2009.

23. Hoang BH, Kubo T, Healey JH, Sowers R, Mazza B and Yang R: Cytoplasmic and/or nuclear accumulation of the beta-catenin protein is a frequent event in human osteosarcoma. Int $\mathrm{J}$ Cancer 109: 106-111, 2004.

24. DasGupta R, Kaykas A, Moon RT and Perrimon N: Functional genomic analysis of the Wnt-wingless signaling pathway. Science 308: 826-833, 2005

25. Xie D, Zeng YX, Wang HJ, Wen JM, Tao Y and Sham JS: Expression of cytoplasmic and nuclear survivin in primary and secondary human glioblastoma. Br J Cancer 94: 108-114, 2006.

26. Tetsu $\mathrm{O}$ and Frank MC: B-catenin regulates expression of cyclin D1 in colon carcinoma cells. Nature 398: 422-426, 1999.

27. Utsunomiya T, Doki Y, Takemoto H, Shiozaki H, Yano M and Sekimoto M: Correlation of beta-catenin and cyclin D1 expression in colon cancers. Oncology 61: 226-233, 2001.

28. He TC, Sparks AB, Rago H, Hermeking H, Zawel L and Costa LT: Identification of c-myc as a target of the APC pathway. Science 281: $1509-1512,1998$

29. Shimokawa T, Furukawa Y, Sakai M, Li M, Miwa N and Lin YM: Involvement of the FGF18 gene in colorectal carcinogenesis, as a novel downstream target of the beta-catenin/T-cell factor complex. Cancer Res 63: 6116-6120, 2003.

30. Sparks AB, Morin PJ, Vogelstein B and Kinzler KW: Mutational analysis of the APC/B-catenin/Tcf pathway in colorectal cancer. Cancer Res 58: 1130-1134, 1998.

31. Thomas RM and Hargest R: APC, B-catenin and hTCF-4: an unholy trinity in the genesis of colorectal cancer. Eur J Surg Oncol 29: 107-117, 2003.

32. Segditsas S and Tomlinson I: Colorectal cancer and genetic alterations in the Wnt pathway. Oncogene 25: 7531-7537, 2006.

33. Watson AJ: An overview of apoptosis and the prevention of colorectal cancer. Cri Rev Oncol Hemat 57: 107-121, 2006. 
34. Yamada Y, Oyama T, Hirose Y, Hara A, Sugie S and Yoshida N: B-catenin mutation is selected during malignant transformation in colon carcinogenesis. Carcinogenesis 24: 91-97, 2003

35. Städeli R, Hoffmans R and Basle K: Transcription under the control of nuclear Arm/beta-catenin. Curr Biol 16: 378-385, 2006.

36. Mi K, Dolan PJ and Johnson GV: The low-density lipoprotein receptor-related protein 6 interacts with glycogen synthase kinase 3 and attenuates activity. J Biol Chem 281: 4787-4794, 2006.

37. Shan BE, Wang MX and Li RQ: Quercetin inhibits human SW480 colon cancer growth in association with inhibition of cyclin D1 and survivin expression through Wnt/B-catenin signaling pathway. Cancer Invest 27: 604-612, 2009.

38. Kundu JK, Choi KY and Surh YJ: B-catenin-mediated signaling: a novel molecular target for chemoprevention with antiinflammatory substances. Rev Cancer 1765: 14-24, 2006.

39. Dihlmann S, Klein S and Doeberitz MK: Reduction of B-catenin/ T-cell transcription factor signaling by aspirin and indomethacin is caused by an increased stabilization of phosphorylated B-catenin Mol Cancer Ther 2: 509-517, 2003.
40. Ambrosini G, Adida C and Altieri DC: A novel anti-apoptosis gene, survivin, expressed in cancer and lymphoma. Nat Med 3: 917-921, 1997.

41. Yie SM, Lou B, Ye SR, He X and Cao M: Clinical significance of detecting survivin-expressing circulating cancer in patients with non-small cell lung cancer. Lung Cancer 63: 284-290, 2009.

42. Vallböhmer D, Kuhn E, Warnecke-Eberz U, Brabende J and Hoffmann AC: Failure in down-regulation of intratumoral survivin expression following neoadjuvant chemoradiation in esophageal cancer. Pharmacogenomics 9: 681-690, 2008.

43. Kim PJ, Plescia J, Clevers H, Fearon ER and Altieri DC: Survivin and molecular pathogenesis of colorectal cancer. Lancet 362: 205-209, 2003.

44. Ma H, Nguyen C, Lee KS and Kahn M: Differential role for the coactivators $\mathrm{CBP}$ and $\mathrm{p} 300$ on TCF/ $/$-catenin-mediated survivin gene expression. Oncogene 24: 3619-3631, 2005. 